sciendo

DOI: $10.2478 /$ jolace-2021-0021

\title{
Time in literary translation: Anticipation of retrospection, temporality of reading and living
}

\author{
Alebachew Fentaw ${ }^{1,2}$, Tesfaye Dagnew ${ }^{2}, \&$ Ayenew Guadu ${ }^{2}$ \\ ${ }^{1}$ Debark University, Gondar, Ethiopia \\ ${ }^{2}$ Bahir Dar University, Ethiopia \\ alexfentaw2@gmail.com
}

\begin{abstract}
Aiming at explicating structural prolepsis, and how temporality of reading and living are related, the study was conducted on Tell Me Your Dreams (1998) and its respective Amharic translation (Hilimishn AchawichgnUஎ story without excursion. But the Amharic translation is not; there is no structural prolepsis. The present is constructed retrospectively and reveals that the best of times is yet to come in the English novel; the future has a retrospective significance of meaning to the present. There is a hermeneutic circle between the presentification of reading the English novel and the depresentification of real life present. The present of the English novel and the lived present of real life are experienced in preterite form in relation to a future to come. The future of real life and the English narrative are the same for both are unknown and imagined. The A and B philosophy of time solidified the literariness of the English narrative, but temporal becoming is emphasized in the Amharic translation. The past has just been, and so is not; the future is to be, and so is not yet. Thus, its literariness can't be sensed.
\end{abstract}

Key words: A and B theories, anticipation, living, prolepsis, retrospection, time, translation

\section{Introduction}

Translation is an act of transfusing the essence of a source text (ST) into a target text (TT). It is transferring the message of the ST into the TT; message and the modes operandi through which the message is expressed are the bedrocks of translation (Ghazala, 2008; Newmark, 1981, 1988, \& 1991). Catford (1965) attests that translation is representing a text in one language into another one. It, as Nida and Taber (1969) contend, is structuring the meaning and style of a text within another text in a different language. A good translation transfers the message of a source text clearly into a target one.

Translation is gripping the meaning of a source text and "the subsequent production of an equivalent text" (Singh \& Warwal, 2014). As Catford (1965) argues, it is the replacement of textual material in the source language text by equivalent textual material in the target language text. It is "the process of conveying the message by transferring from one system of language to the other" (Akan, 2019, p. 1). As Bassnett (1980) and Nida and Taber (1982) contend, translation deals with message transfer. Hatim and Munday (2004) and Baker (1992) emphasize that translation is repositioning meaning of a source text into a target one. To be credible, translation must transfuse meaning and form of the source text into a target text.

Literary translation focuses on literary genres; it is transferring the literary features of a source text (ST) into a target language text. Ghazala (2015), for example, argues that it is a typical type of translation for it focuses on the genres of literature.

According to Marabout (2010), literary translation is concerned with translating texts written in a literary language. Translation scholars agree that literary translation is a vehicle 
of cultural transmission as well as it is an art. El-Haddad (1999), for instance, argues that literary translation is transfusing style and meaning of a literary work into a target text; and thereby, different societal and cultural aspects in the ST are transferred into the target text.

As Belhaag (1997), cited in Hassan (2011), claims, literary translation comprises typical features. It is expressive, connotative, and symbolic. Also, it focuses on both form and content. Gutt (1991) contends that the style of the original text should be preserved in literary translation. Hence, literary translation transfuses culture, style and meaning from the source text into the target text, bridges the gaps between cultures and should reflect all literary features of the source text.

This study focuses on time in literary translation, one aspect of translation. Time is one of the basic elements of a source text that has to be transfused into the target text. Anticipation of retrospection or structural prolepsis is the specific focus of this study. This aspect of prolepsis is somewhat different from what is generally known from this term in the history of narrative study. Its meaning, widespread in narrative studies, is that a deliberate deviation from the chronological ordering of the story-a flash forward-that consents the reader a privileged access into the state of affairs of the future, Currie (2007) contends. But, to achieve the objective of this study, the meaning of the term covers a more generalized aspect of the experience of reading and narrating in which anticipation plays as much a part in shaping our experience and understanding of the story's present as is played in memory. Currie's (2007) classification of prolepsis reveals the basis for the subsequent use of the term. The meaning of this term corresponds with what Currie (2007) identifies as 'structural prolepsis' or "anticipation of retrospection" which is a "property of all fictional narrative" and not merely a dramatic device that conducts an intentional excursion into the future of the story (p. 32). The structure of the present inferred in this idea is that of a present "lived as the object of future memory" or a mode of consciousness that experiences the present in the anticipation of retrospect from a projected vantage point in the future that retrospectively assigns significance meaning to the present of the story. One of the methods in which the human mind impels itself towards the lived experience of time is through the medium of narrative activity. The reliance of human beings on narratives can be characterized as cognitive necessity. From this argument, it can be inferred that ordering of human experience is one of the primary functions of narratives.

Currie has identified a more pervasive kind of prolepsis that is "placed between the narratological and the rhetorical prolepses as a kind of bridge: the anticipation of retrospection which offers the beginnings of a theory connecting the temporality of reading with the temporality of living. The connection that it offers between reading and life can be expressed in the following preliminary proposition that "there is a hermeneutic circle between the presentification of fictional narrative and the depresentification of lived experience" (Currie, 2007, pp. 31-32). The present of fictional narrative and the lived present of real life are experienced in the preterite form and found in the" future anterior mode". But this aspect of time has not been studied in literary translation in Ethiopia. The objective of this study was therefore to explicate anticipation of retrospection and how temporality of reading and living are related in Tell Me Your Dreams (1998) and its respective Amharic, the widest spoken language in Ethiopia, translation (Hilimishn Achawchign- Uর9 theoretical points of reference of Mark Currie's (2007) About Time and Reiss's (1989) theory of translation. 


\section{Methodology}

A qualitative approach has been applied for this approach provides detailed explanation and analysis of the quality or substance of the human experience. It yielded the essential components to investigate the meaning of structural prolepsis-anticipation of retrospectionbased on the context. As Creswell (2007) argues, through this approach, the experiences of characters, in both texts, are explained in words. Specifically, narrative design was employed to tease out the implicit meaning of prolepsis in the source and target texts. As Webster and Mertova (2007) and Riessman (1993) claim, a narrative inquiry analytically examines the narrative as an object of study to explicate its implied meaning. This design helped the researchers to make and compare the implied meaning of structural prolepsis in the English novel and its respective Amharic translation. This design was also helpful to identify how every event is connected through structural prolepsis in the story.

The English novel was selected purposively. The novel was intentionally selected by the researchers from the novels written from 1985 to 2000 based on the assumption that what is selected to be studied should be information rich, as Patton, (2002 claims, for the novels in the time range stated above feature mainly anticipation of retrospection and recollection of anticipation that make the narrative suspenseful. In addition, many English novels were translated into Amharic in Ethiopia in the period stated above. The inclusion criteria are recollection of anticipation, and anticipation of retrospection. Especially, the novel was selected for it has feature of anticipation of retrospection to develop enigmatic and tragic aspects of life and to reveal best and worst of times in the story.

The methods of data extracting include examining the novel thoroughly, reading critically and identifying the extracts based on Currie's (2007) model of time analysis and the objectives set. While reading, the researchers considered the lived present of the real life and the present of the fictional narrative, temporality of living and reading respectively.

Hermeneutics was applied for the study aimed at understanding, interpreting and explaining how time was used and making its meaning. As stated in Tavakoli (2012), in hermeneutics, reality is constructed socially. As Gadamer (1975) asserts, hermeneutics is not about locating or fixing truth; rather it is about the on-going process of understanding the conditions necessary for understanding to occur. Gadamerian philosophical hermeneuticsdetail understanding of a text and life as a whole-was applied. Thus, to interpret how time was used in the texts, we read the data (the English novel and its translation) repeatedly and critically and extracted texts, teased out meaning and constructed the holistic sense of the texts.

The researchers used a variety of techniques to establish credibility, transferability, dependability, and conformability of the study. To maximise authenticity of the present research, we employed member checking because Bowen (2005) argues that this method enhances credibility.

As stated in Webster and Mertova (2007, pp. 258-260), validity, in narrative research, is maintained when four basic criteria are realized in the analysis: "persuasiveness", "correspondence", "coherence" and "pragmatic use". To realize the above criteria, we applied "Transcategorial reading" suggested by Ryan. According to Ryan (2007, p. 25), it refers to the way of reading narrative texts as "propositions" and reading them against the grain: "use the texts in games for which they were not necessarily intended".

To apply the above type of reading, we read the novels in line with the time analysis model of Currie (2007) though the narrative doesn't intend to be read in that way. The English novel and its Amharic translation were read in search of pattern of structural prolepsis. Also, careful 
scrutiny of the methods and the data helped the researchers to substantiate the credibility of the interpretations. We applied bracketing (putting our perceptions, personal beliefs, and bias aside) past experiences, as (Saldana, 2011) claims, about the texts. In addition, we had this study debriefed by our peer researchers. We had the study examined by our peers. The impartial peers examined this report and general methodology. We let our colleagues to detect overemphasized and underemphasized points and vague descriptions, general errors in the data and biases or assumptions made by us.

Both the process and the product of the research need to be consistent to meet dependability (Lincoln \& Guba, 1985). The process of the research work and the method of meaning construction are consistent; the researchers applied audit trail (e.g. different types of personal notes) that can also be used by another researcher to check and come up with nearly the same general understandability, flow of arguments, and logic. According to Bowen (2005) conformability in qualitative research is concerned with characteristics of data. To achieve conformability, all the discussions and findings of this research are based on the English novel and its Amharic translation. Triangulation is impossible in narrative analysis. Thus, to realize conformability, we analysed, interpreted and found patterns in the narrative based on the model of time analysis in narrative formulated by Currie (2007).

\section{Findings}

This study was conducted to explicate structural prolepsis in the English-Amharic literary translation. Tell Me Your Dreams (1986) is anticipation of retrospection. It comprises the force that makes a reader keep on reading a story, structural prolepsis. It is one of the aspects of time that propels reading without excursion. It is so analytical a device that makes the text inspiring and impelling while it is being read. It has a propelling feature. It, thus, entices a reader to keep on reading the narrative.

But its Amharic translation is not anticipation of retrospection because of the aporia. There is no structural prolepsis for time is distorted. It doesn't maintain the time aspects of the English novel. It is mainly in the present form and sometimes in the preterite form. The present is not constructed retrospectively, and the future of the narrative doesn't have retrospective significance to the present. The anticipation of retrospection illuminates what has been read and is being read.

The present of the English narrative is constructed retrospectively. The future has a retrospective significance to the present. There is a hermeneutics circle between the presentification of reading the English novel and the depresentification of real-life present that makes anticipation of retrospection the feature of both actions because we anticipate the past in the narrative reading and experience the present of real life as the object of future memory. The future of real life and the fictional narrative, although the former is open and the latter is closed, are the same as they are found ahead, and we do nothing except imagining to the unknown in both cases. A reader presentifies-constructs the present retrospectively-the English narrative as it is in the preterite form while he/she depresentifies his real-life present time in living.

But in the Amharic translation, there is no hermeneutics circle between the depresentification of real life present and the presentification of reading the narrative that makes the anticipation of retrospection the feature of both because of the aporia; the translation is not in the preterite form. Readers don't have the task of presentifictaion for the narrative is presentified by the translator. 
Structural prolepsis, in Tell Me Your Dreams (1986), directs a reader forward to see backward. The reader keeps reading to make sense of what is particularly being read, and what has been read as what could be read illuminates what is being read and has been read.

The reader depresentifies what he reads to feel it as if it happened to him/her. The real present doesn't play its metaphysical role as it robs us of the present to sense the meaning of the narrative retrospectively, and the reader keeps on heading forward due to the anticipation in each statement without excursion. The present is constructed retrospectively/quasipresent and the future has a retrospective meaning to the present. The structural prolepsis, as it is the powertrain of the narrative, makes the conflict suspenseful, and the plot interwoven.

Recollection of anticipation-controlling the unfolding of a horrific future or something mysterious in the form of forgetfulness, ignorance or teleological retrospect-stalking in this case, through ignorance-is found. It is prolonging mysterious issue about stalking that is structured without key information of the issue Ashley (protagonist) is going to confront. It reveals that the character never knows who is stalking her and never does she know who shall be: "Someone was following her. She had no idea who it could be, who would want to harm her" (Tell Me Your Dreams, 1986, p.1). This quoted idea suppresses who and why stalks her. This reveals that the structural prolepsis comprises retrospective anticipation. The expression projects forward; it makes readers develop a question of curiosity of what could happen to the protagonist and who it could be that stalks her. This is the propelling force, structural prolepsis.

The structural prolepsis lets us think of forward to understand the backward and to think of forward again. The essence of time is generated from the intermingled form what is being read what could appear and making sense of the past. This makes the text appealing and suspenseful. The structural prolepsis and retrospective anticipation inspire a reader to go on reading. The forward and backward thoughts about the events in the narrative are due to the style of expressing time of the events in the narrative. The style of expressing time and meaning of time constructed have a great contribution in developing comprehensive imagery, mood, tone, and rhetoric. The style of intermingling events through time makes the conflict attention seeking and the plot enthusiastic. Let us consider the following extract to see how time interweaves events in the English narrative:

Someone was following her. She had read about stalkers, but they belonged in a different, violent world. She had no idea who it could be, who would want to harm her. She was trying desperately hard not to panic, but lately her sleep had been filled with unbearable nightmares, and she had awakened each morning with a feeling of impending doom. Perhaps it's all in my imagination, Ashley Patterson thought. I'm working too hard. I need a vacation (Tell Me Your Dreams, 1998, p. 1).

There is no excursion in the above quoted extract, but a hovering sense of anticipation is introduced through suggestions which indicate that the unfolding of subsequent actions will take place. The quoted ideas reveal actions that would happen in the future. There is anticipation without excursion.

The narrative inspires the reader to keep on reading as it at least includes two questions that let the reader anticipate: who did follow her and why? What could happen to her? What Currie (2007) argues about resonates through the narrative. As Currie (2007) makes it clear, a narrative is written in preterite form of time to "install in the present an anticipated future from which the present will be re-experienced as representation of the past" (p. 41). In the above extract, more illumination to the present narrative is constructed from the anticipated 
part of the narrative because the future part of the narrative justifies what has already been read and even what is being read. In other words, each statement echoes backward, in addition to the meaning it comprises, to make what has already been narrated clearer. This makes the reader cast back over what he/she has read and understand better what he/she has already read. Furthermore, each statement has an anticipation feature to answer the "and then, and then?" question: the present/what is being read makes a reader to retain anticipation. The questions like "Who was stalking her? Who are the stalkers she had read about? Why were they stalking her?" will be answered from the future part of the narrative. The anticipation is structural prolepsis, blood and soul of the narrative; it makes a reader keen to know who and why stalks the protagonist.

To make sense of the experience of the characters, a reader presentifies the narrative while reading it. Liberating again him/herself from the realm of the present time of the narrative, he/she imagines, recollects and makes senses of the then present of the characters. The reader anticipates the retrospect, presentifies it, and makes sense of it. Though the text was written in the preterite form, it doesn't denote its direct meaning of its utterance. The structural prolepsis has a meaning of forwarding motion-the meaning of time is future oriented. The meaning of time in the above quoted idea is anticipation between the time locus of the narrated and the time locus of the narrator, structural prolepsis. As Currie (2007) argues, "When we read a novel, we make present events that are in the past" (p. 41). While reading a novel, readers decode past story as a present. The utterance of the novel introduces the central issue: the protagonist is being pursued and knows nothing who traps her; she is scared. Time, in the English text, is a sequence of events all of which are equally real, and between which the only relations are those of earlier than and later than.

However, the Amharic translation of the novel, Hilimishin Achawchign, is not expressed in the preterite form of time because of the aporia. Hence, it is not anticipation of retrospection. It metaphysically privileges the present. The features of time of the English extract explained so far are not found in the Amharic text. The style of expressing time in the Amharic textdiction, and syntax don't help a reader to construct structural prolepsis and retrospective anticipation to understand the narrative. There is no organic unity, but temporal becoming resonates. Let us consider the following extract:

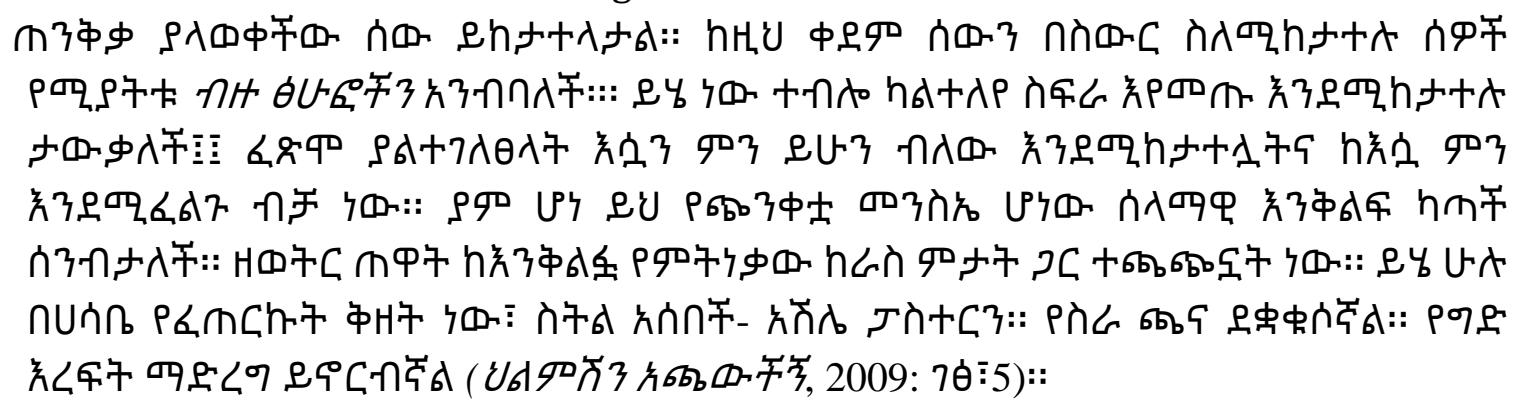

The first statement in the above quoted idea reveals that she, though not well, knows who stalks her; it doesn't represent the English one because it says, "A man whom she doesn't know well stalks her". The second one implies that she read a lot about criminals who had stalked people before, but both ideas are not found in the English novel. There is no unfolding of actions that would happen subsequently. The narrative isn't in the preterite form; it has been almost written in present tense form; as a result, it doesn't let a reader to construct the structural prolepsis and retrospective anticipation. The Amharic text doesn't have what Currie 
(2007) says it is so analytical a device that makes a text gain a forward motion of meaning of the narrative, structural prolepsis.

The English text is in the preterite form of time with propelling events that make the reader anticipate, but the Amharic text is written in the present form of time that doesn't include structural prolepsis and retrospective anticipation. These aspects of the narrative are among the inspiring forces that provoke the reader to be keen to keep on reading. But the essence of structural prolepsis is not found in the Amharic text. It comprises the feature of informative [literal] text while it is supposed to be expressive [literary] text-the creative composition wherein the artistic dimension of language is considered (Reiss, 1989). The expression of time in the English text, though it is expressed in the preterite form, gets a reader to anticipate to see backward or it makes a reader to anticipate the past and to re-experience the then present, which is what Currie (2007) calls structural prolepsis.

But the Amharic translation doesn't comprise structural prolepsis and retrospective anticipation as are used in the English text. The preterite form of structural prolepsis was changed into present form denoting merely its direct meaning. The structural prolepsis is distorted for its time zone is altered and comprises content that is not found in the English text

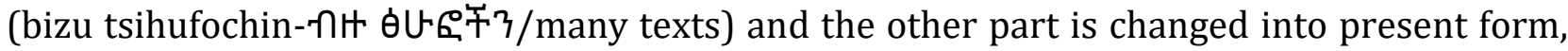
regular action, whose meaning is not found in the source text. The structural prolepsis and retrospective anticipation became present regular actions and represent objects and facts in a distorted form. The retrospective anticipation-"She had no idea who it could be, who would want to harm her"- which is also structural prolepsis at the same time is totally altered into a

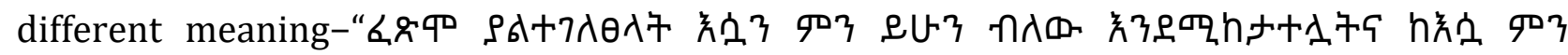
玄 that the character can't predict who the stalkers could be and why they would want to hurt her, but the Amharic extract reveals as though she knew because nothing is stated to reveal that she is unaware of the stalkers.

The following extract comprises structural prolepsis. The whole extract is structural prolepsis. It is in preterite form, and it helps the reader to anticipate the past, re-experience the then present and goes back to understand it. Let us see the following quoted extract:

... And it would end the same way. Her date would lean close to her and whisper in her ear, "Why don't we go up to my flat and have shag?" "Buzz off." And Toni would be out of there. She would lie in her bed at night, thinking about how stupid men were and how bloody easy it was to control them. The poor sods did not know it, but they wanted to be controlled.

They needed to be controlled (Tell Me Your Dreams, 1998, p. 10).

The extract indicates that each statement anticipates. It reveals events that are future driven. This is anticipation without excursion. The structural prolepsis reveals that screwing is the intuitive nature of men, and how Toni becomes against shagging and intends to denigrate men, but the way the issues are structured has a forwarding meaning for the whole extract is nearly stated in preterite form of time and it has a question of curiosity: why does she refuse men's question for partnership? Every statement has an anticipated feature due to implicit questions of curiosity and the forwarding nature of the events. So does the extract comprise recollection of anticipation, why did men want to be controlled?

Each of the statements, in the above extract, picks up speed and they are interconnected in their forwarding force, feature of structural prolepsis. Each statement propels to its posterior one, and at the same time, the reader anticipates and thinks retrospectively to make sense of the narrative. The sentences project forward. The English text comprises a continuous chain of events due 
to structural prolepsis. Times of events are interconnected as they share ideas with each other and as all events of time exist equally.

But the above meaning of time is not found in the Amharic text and the Amharic extract plays the role of informative text, representing only objects and facts of the source text. It seems to be logical instead of being literary and artistic with regard to time for it mainly deals with temporal becoming. It, abolishing literary essence of time due to aporia, transmits referential content. The time applied is the present form of time with its denotative meaningrevealing regular and future actions. Let us see the following extract:

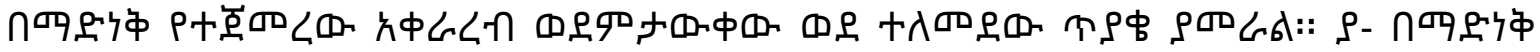

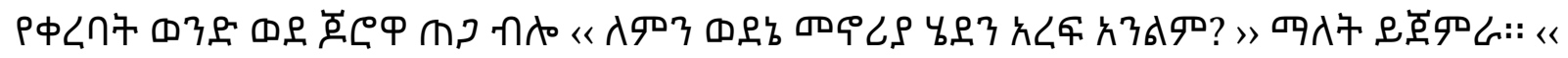

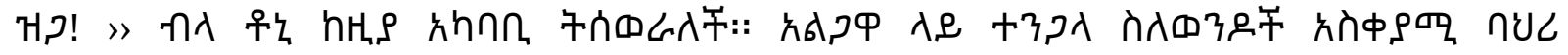

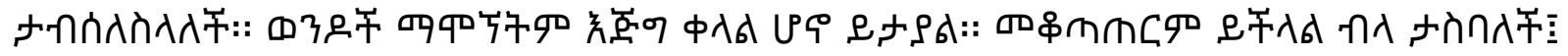

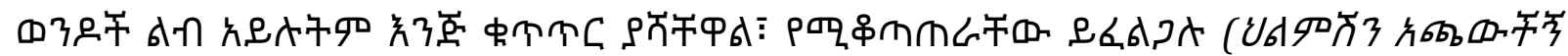

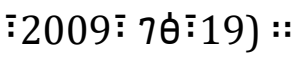

The above extract doesn't comprise structural prolepsis for it is not anticipation of retrospection. There happens collapse of meaning as there is no literary essence of time. The time aspect is changed from preterite form of time into ordinary present form of time-there is direct relationship between the utterance of the narrative and what it refers to. The meaning of the first statement is not found in the English narrative at all and nor is the part of the second

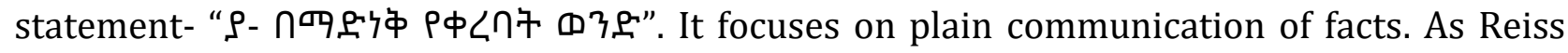
(1977/1989) argues, the language dimension, in the informative text, used to transmit the information is logical or referential; the content or topic is the main focus of the communication. This feature of the informative text is found in the above extract.

The structural prolepsis is stated in relative terms and preterite forms and leads to anticipation. Let us see this extract: "Would Jim Cleary be there? Would he have a wife and children? What would he say to her? "Sorry I wasn't able to meet you at the train station. Sorry I lied to you about marrying you?"' (Tell Me Your Dreams, 1998, p. 22). The extract above is anticipation of retrospection for the statements comprise actions that would occur subsequently.

In the Amharic translation, nonetheless, the structural prolepsis is changed into future form time with a literal text meaning of time. The temporal aspect of the English text is changed into other form of time in the Amharic translation. When this is so, the narrative and its meaning are changed into another narrative that is not the equivalent translation of the source text; when, Reiss (1977/1989) attests, literary translation takes place, the target text should contain artistic aspects and meaning of the source text. But the Amharic translation lacks the artistic aspects and meaning of time of the English text. It loses innocence and creativity, and the power of literary language due to the distortion of the meaning of time. Let us note this extract: "占g

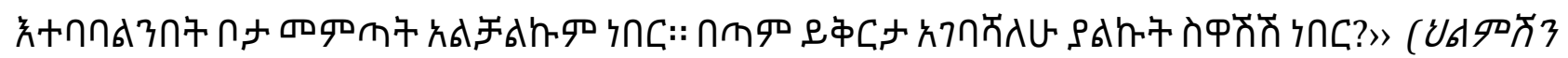

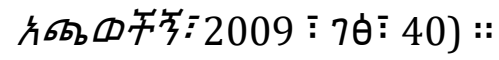

The idea seems to be reproduced, but the artistic expression of time and its meaning in the source text were not reproduced into the target text for what the Amharic translation comprises is the mere future form of time. The Amharic text doesn't comprise the intermingled 
form of retrospective anticipation and structural prolepsis that gets a reader to anticipate and acquire suspense.

The interwoven form of structural prolepsis and retrospective anticipation in the English text is used to express Ashley's trauma, her effort to restore her stable mental status, and what she did in the strange and unpredictable bed room. Retrospective anticipation which is the part of the structural prolepsis has an accelerating contribution on reader's anticipation. Let us consider the following extract:

Trying not to think about it [having sex with Dennis Tibble and killing him], she got out of bed, walked into the tiny bathroom and stepped into the shower. She let the stream of hot water pound against her body, trying to wash away whatever terrible, dirty things had happened to her. What if he had gotten her pregnant? The thought of having his child was sickening (Tell Me Your Dreams, 1998, p. 30).

In the above quoted idea, structural prolepsis pokes forward and the reader becomes keen to know what could happen. It comprises retrospective anticipation-that includes the threat about pregnancy, thought about it and sickening due to thought about pregnancy. Also, the last two statements are in the sense of retrospective anticipation for they reveal how her future was structured without the key information-not being sure whether she could be pregnant and thinking about having his child without being sure even about the pregnancy. The concepts stated above are intermingled in an inviting fashion.

The Amharic text whereas is devoid of the time aspects of the English text stated above.

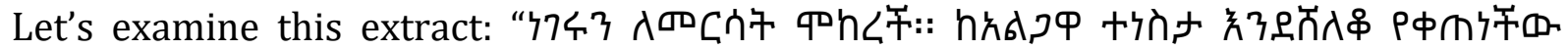

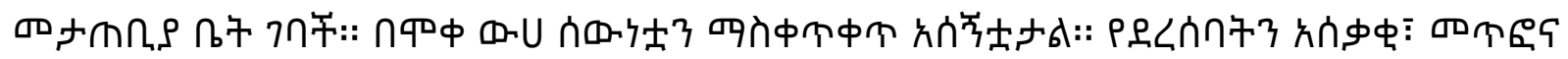

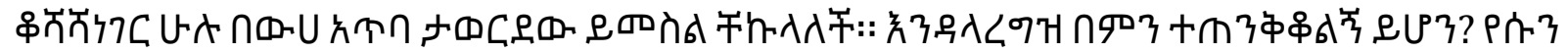

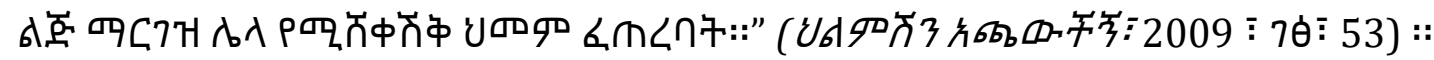

The above extract doesn't represent the English extract as it doesn't reflect the essence found in the English text. The time at which the events are stated is not the equivalent form of the time used in English text. The structural prolepsis about forgetting is not found in the Amharic text at all or the time used to express forgetting is not the time used in the English

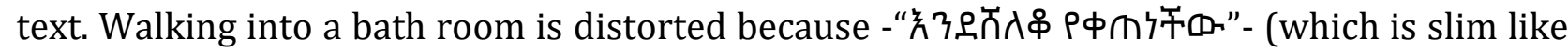
a valley) is not found in the English narrative; stepping into shower was discarded; the time of the event about hot water is changed into wish as though she wanted to let the stream of hot water pound against her body, but the English narrative testifies that she let the stream of hot water pound against her body. The structural prolepsis was changed into present form of time with a common sense meaning of time. The question formed with structural prolepsis is

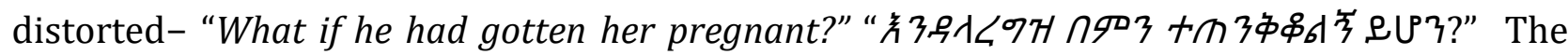
Amharic text doesn't represent the statement found anterior to it. It is rather equivalent to "What did he do not to get me pregnant?" which is not found in the English text. The time forms and meanings are distorted and dispersed. As a result, the plot structure is distorted.

The English text is written in the most conventional way of writing a narrative, preterite form of time. It was written in preterite form considering its future significance as a primary temporality. It gets a reader anticipate the past. These actions go on and on till the reader finishes reading the narrative as structural prolepsis is the force that makes the reader keep on reading the narrative. The preterite form of time makes the reader imagine and sense Ashley's horrified mental status because of the problem she faced when she had been with Dennis Tibble. Let us ponder the following extract: 
When Ashley got back to her apartment, she felt as though she had returned to a sanctuary. She could not wait to get out of the tacky outfit she was wearing. She stripped it off as quickly as she could. She felt as though she needed another shower before she met her father. She started to walk over to her closet and stopped. In front of her, on the dressing table, was a burned cigarette butt (Tell Me Your Dreams, 1998, p. 31).

The narrative makes the reader busy and active for she/he reads it iteratively to make sense of the narrative. The extract includes events that would happen subsequently. The subjective mood testifies that Ashley doesn't get relief. But the Amharic text reveals that she got as time of the narrative is distorted. There is an idea expressed in present form about hope of protection aspect of her house in the Amharic text, but this is not found in the English text. Let us consider the following extract:

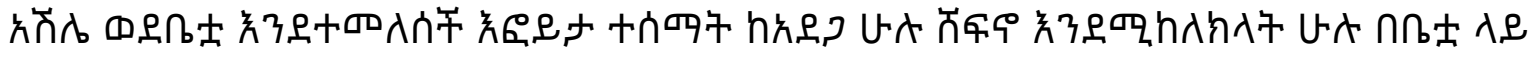

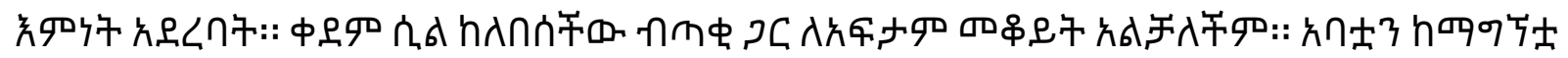

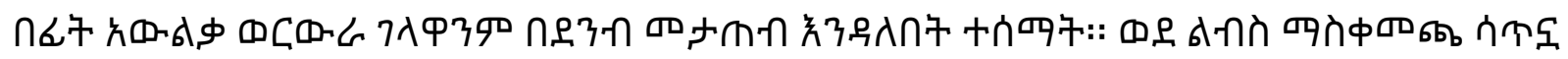

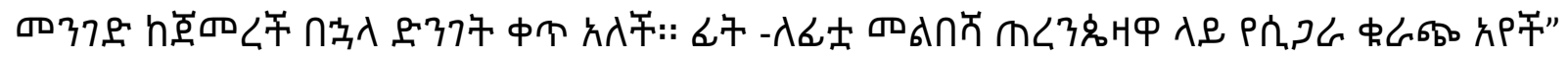

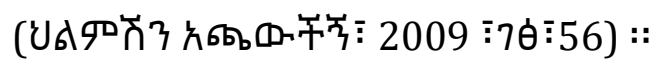

The Amharic text is not equivalent form of the English text with regard to structural prolepsis. The structural prolepsis is with a propelling meaning in the English text. The ideas about getting out of the tacky outfit and striping off that cloth and the intention of another shower (expressed with future oriented past aspect of time) are part of structural prolepsis. The Amharic text doesn't have the structural prolepsis as it is changed into present form of time with its direct grammatical meaning. The style of expression of time is distorted. Even "Stripping the tacky outfit off ..." has not been translated into Amharic.

Time in the English text is used to reveal zeal to dinner; how astonishing evening it could be, and dressing and singing have an impelling meaning though expressed in the preterite form of time-the four actions are springing forward. Let us see this extract: "Toni was looking forward to dinner with Jean Claude. It was going to be a lovely evening. As she dressed, she sang softly to herself" (Tell Me Your Dreams, 1998, p. 46). Could she have a lovely evening? Could there be something else? The meaning of time in the text impels forward without intrusion though expressed in the preterite form because the events are to take place

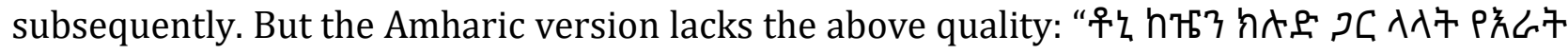

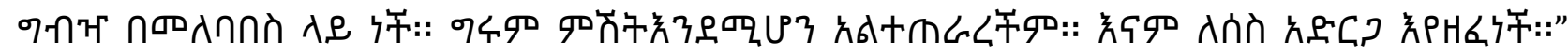

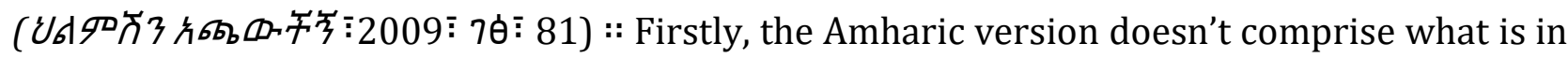
the English extract. The first issue, looking forward to dinner, was discarded. The rest parts are distorted in the Amharic text. Dressing comes first, expecting that it would be a lovely evening follows and singing appeared at the end. The time aspects used in the Amharic text include present continuous and present tense with their denotative meaning. The style of expressing time is not appealing for it lacks anticipation of retrospection: structural prolepsis.

The way the narrative is organized and stated is used to reveal the stress that the protagonist faces with regard to the cell she is in-her thought about sentence to death, and sobbing, and lets a reader anticipate. The structural prolepsis gets a reader to sense the long death, thought about endless and hopeless years. The structural prolepsis reveals that the protagonist wished she had been killed. This reveals that the anticipation of retrospection 
comprises retrospective anticipation. The essence of the narrative is that the protagonist doesn't know why she is in the cell. The narrative interweaves recollection of anticipation and anticipation of retrospection. She is ignorant about why she was jailed. Though she had killed men who went to her for love, she was not aware that she killed them for she committed the crime due to dissociative identity disorder. The time aspects are intermingled and reveal that the character is suffering from a trauma and a depression due to a gloom future. These points get a reader anticipate what then could happen. Let us see the following extract:

In her cell, Ashley thought. They've sentenced me to death. A long death in an asylum filled with crazy people. It would have been kinder to kill me now. She thought of the endless, hopeless years ahead of her, and she began to sob (Tell Me Your Dreams, 1998, p. 157).

The extract includes events that could happen. What could she face in the cell? Could it be as difficult as she predicts? Questions like the aforementioned ones inspire the reader to keep on reading and anticipating. He/she goes on reading to get illumination about what is being read. The overall atmosphere reveals that the protagonist doesn't have solid information about what could happen: recollection of anticipation. This enhances suspense in the narrative.

But the Amharic text distorts the time structure used in the English text. Let us consider

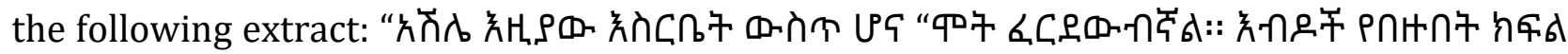

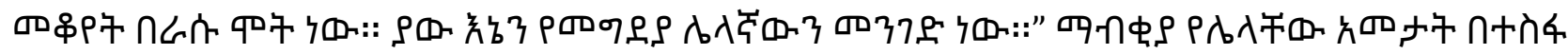

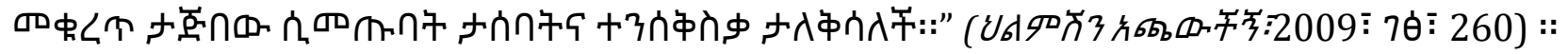

The first line of the text is non-sense. The second statement is not found in the English text. It might be the distorted form of the third statement in the English text; the last statement might also be the distorted form of the last statement of the English text. The Amharic text is in present form of time with denotative meaning which is not the feature of time in the English text; it does not have the sense of anticipation of retrospection when read. The Amharic translation doesn't get the reader to anticipate. As Currie (2007) states, if a text is written in preterite form of time, the reader decodes the past tense as a kind of present. This is the interaction between the temporality of the narrative and that of the reader. The reader doesn't perform the actions what Currie (2007) argues about while reading the Amharic text.

In the English text, the structural prolepsis comprises recollection of anticipation. Let us see the following extract: "I had to protect you," Toni explained. I suppose every time I killed one of those men, I was killing Father for what he had done to you" (Tell Me Your Dreams, 1998, p. 192). Did she really protect her? The reader anticipates understanding the past and even to better understand what she/he is reading for the part of the narrative that has not yet been read illuminates what has already been read and even what is being read. The time aspect includes a propelling meaning of time, structural prolepsis: "I had to protect you". This aspect of time shows the impelling nature of meaning of time, without excursion, to know what happened then. The recollection of anticipation reveals something is done, but the protagonist did not know why that was done. It has a role of propelling the narrative, and it inspires the reader to keep on reading for the recollection of anticipation develops suspense.

But the Amharic text is not organized in the way the English text is with regard to time and the overall atmosphere. At the very beginning of the text, it applies present form of time which is ambiguous-it has present and future meaning. Nor does it contain structural prolepsis form of time. The reasons stated so far reveal that the Amharic text includes meaning of time that is 


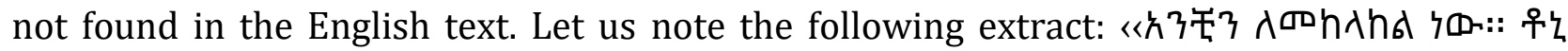

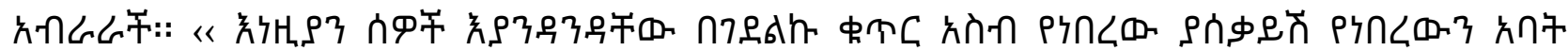

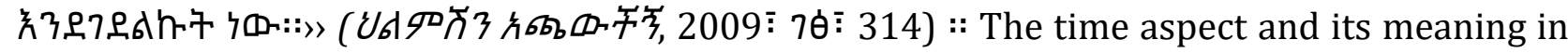
the above text are not equivalent to the time in the English text because the meaning of time and the overall atmosphere are not found. The content seems to be translated, but the style of expression of time usage is misleading. The narrative lacks what Currie (2007) claims about: "A fictional narrative encourages us to think of the past as present no more than it encourages us to think of the present as a future past" (p. 16). The Amharic text doesn't do what Currie claims. In the English narrative, we are narrated to in the preterite, but we experience someone's present in the past tense, but these actions are not performed by the Amharic text's reader for the time structure is changed.

According to Currie (2007), structural prolepsis is a form of anticipation "which takes place between the time locus of the narrated and the time locus of the narrator" (p. 42). Recollection of anticipation, Currie (2009) states, is the anticipation of the character that is used to prolong the mysterious issue in the narrative to enhance suspense. On the other hand, Reiss (1977/1989) emphasises equivalence at text level, links language functions to text types and translation strategy. Text type theory considers the text, rather than the word or sentence to achieve equivalence and communication. It is all about the creative composition wherein the text includes artistic dimension of the language, emphasis on poetic communication. If not, text becomes informative text: "plain communication of facts": information, knowledge, opinions, etc. The language dimension used to transmit the information is logical or referential; the content or topic is the main focus of the communication. Therefore, the English text, as it comprises the intermingled form of structural prolepsis and retrospective anticipation, is anticipation of retrospection; it is anticipation in retrospection. But the Amharic text doesn't comprise what Currie (2007\&2009) argues about and what Reiss (1977) claims, poetic communication. It is rather plain communication of facts. The literary essence of the English text is not transfused into the Amharic text; the Amharic text lacks artistic feature of the English text. The possible reasons can be the translator's knowledge of the cultural, historical and social contexts of the source text might not be deep enough to translate the source text with its all sensible and literary nature as the mere mastering the source and target languages doesn't suffice.

The study unfolds the truth underneath the common sense beliefs: structural prolepsis, temporality of reading and living. In the English novels is structural prolepsis which is an analytical meaning that makes the whole novels future driven. While reading, a reader keeps on reading anticipating that the best is yet to come due to structural prolepsis, and a hermeneutic circle between the deeds of presentification and depresentification getting us live the present time as though it were not present and reading fictional narrative as if it were. But the Amharic translation is not.

\section{Conclusion}

The structural prolepsis and retrospective anticipation make the English narrative gain a propelling nature without excursion. They help readers to develop forethought. There is a hermeneutics circle of depresentification of real life present and presentification of reading the English narrative. The present of the English novel and the lived present of real life are found in the future frontal mode that is sensed in the preterite tense in relation to a future to come. They are the same for they are experienced in the preterite form. The future of real life and the English narrative are the same because we do nothing except imagining to the 
unknown in both cases; the future in either case is the object of mere speculation and anticipation. The time locus of the narrator states the time locus of the narrated and the time locus of the narrator itself. Anticipation of retrospection interweaves the plot and elements of the English narrative. Thus, literariness is gained and organic unity is well constructed. The aforementioned features of the English novel are not found in the Amharic translation.

Meaning of time is constructed from the interwoven form of the past, the present and the future in the English novel. The interaction of B and A theories of time solidify the meaning of the English narrative. The former one helps readers to view words of statements as co-present in the manner of a landscape of time and the latter one helps readers to consider the experience of reading as a kind of mobile present. Nonetheless, temporal becoming is emphasized in the Amharic translation. There is a temporal confusion as meaning can't be constructed from the interwoven form of the past, present and future. Thus, A-series of time is found in the Amharic translations. Time in the English novel interweaves the plot and the elements of the novel. The anticipation of retrospection defines the past and what is being read or gets us to define it. Therefore, literariness resonates, and organic unity is well constructed, but time in the Amharic translation is distorted; the plot and the elements of the translated narrative are scattered because of the aporia. The Amharic translation reveals that time moves forward to the future like the commonsense meaning of time. The present has a special ontological privilege. As a result, literariness and organic unity aren't maintained.

\section{Acknowledgements}

We respectfully thank Dr. Demeke Tassew for he created us the invaluable space to conduct this study. His constructive and critical comment made us excavate and analyse the different aspects of the issues studied. We are grateful to Dr.Anteneh Awoke as his wise and kind advice; comment and suggestion led us to the destination where we reached. We would like to sincerely thank Dr. Mulugeta Teka for his materials, advice, instigation have formed the basis for our study. What Wusane instigated us is beyond measure and we are grateful to Habtamnesh Adamtie for writing the Amharic translation.

\section{References}

Akan, M. F., Karim, M. R., \& Chowdhury, A. M. K. (2019). An analysis of Arabic-English translation: Problems and prospects. Advances in Language and Literary Studies, 10(1), 5865.

Bassnett, S. (1980). Translation Studies. London and New York: Routledge.

Baker, M. (1992). In Other Words, A Coursebook on Translation. London: Routledge

Bowen, G. A. (2005). Preparing a qualitative research-based dissertation: Lessons learned. The qualitative report, 10(2), 208-222.

Catford, J. (1965). A Linguistic Theory of Translation. London: Oxford: Oxford University Press. Creswell, J. (2007). Qualitative Inquiry and Research Design: Choosing among the five approaches. (2nd ed.). London: Sage.

Currie, M. (2007). About Time: Narrative, Fiction and the Philosophy of Time. Edinburgh University Press. Edinburgh.

El-Haddad, I. M. (1999). An analytical Study of Some Aspects of Literary Translation: Two Arabic translations of Hemingway's The Old. Man and the Sea. (Unpublished PhD thesis). University of Glasgow.

Ghazala, H. (2008). Translation as Problems and Solutions: A Textbook for University Students and Trainee Translators (Special Edition), Dar El- IlmLilmalayin Publishing Press. 
Ghazala, H. (2015). Translating Culture: A Textbook. Jeddah: Konooz Al-Marifa.

Gutt, E. (1991). Translation and Relevance: Cognition and Context. Oxford: Blackwell.

Hans-Georg, G. (1975). Truth and Method. Sheed \& Ward Ltd and the Continuum Publishing Group. Continuum. London. New York.

Hassan, A. B. (2011). Literary Translation: Aspects of Pragmatic Meaning. Cambridge Scholars Publishing.

Hatim dan Munday (2004: 6) Translation, An Advanced Resource Book. London: Routledge. Lincoln, Y. S., \& Guba, E. G. (1985). Naturalistic Inquiry. sage.

Marabout, O. M. (2010). Aesthetic Effect in Arabic-English Literary Translation A Sample from Gibran Khalil Gibran. (Unpublished MA Thesis). Mentouri University-Constantine.

Newmark, P. (1981). Approaches to Translation. Oxford: Pergamon Press.

Newmark, P. (1988). A Textbook of Translation. London: Prentice Hall.

Newmark, P. (1991). About Translation Clevedon. Philadelphia, Adelaide: Multilingual Matters. Newmark, P. (1995). A Textbook of Translation. London: Prentice Hall.

Nida, A. E. \& Taber, R. C. (1969). The Theory and Practice of Translation. United Bible Societies. The Netherlands.

Nida, E. A., \& Taber, C. R. (Eds.). (1982). The theory and practice of translation (Vol. 8). Brill Archive.

Patton, Q. (2002). Qualitative Research and Evaluation Methods (3rd ed.). Thousand Oaks, CA: Sage.

Ryan, M. L. (2007). Towards a definition of narrative. In Herman, D. (Ed.), The Cambridge Companion to Narrative (pp. 22-35). Cambridge: Cambridge University Press.

Reiss, K. (1989). Text types, translation types and translation assessment. Readings in translation theory, 19771989.

Riessman, C. K. (1993). Narrative Analysis. London: Sage.

Saldana,J.(2011). Fundamentals of Qualitative Research. Oxford University Press.

Sheldon, S. (1998). Tell Me Your Dreams.

Tavakoli, H. (2012). A Dictionary of Research Methodology and Statistics in Applied Linguistics. Rahnama Press.

Warwal, S. S. \& Singh, H. (2014). Translation process and problem of translation in world classics. An International Multidisciplinary Research e-Journal, 1(1), 125-133.

Webster, L. and Mertova, P. (2007). Using Narrative Inquiry as a Research Method: An Introduction to Using Critical Event Narrative Analysis in Research on Learning and Teaching. Routledge. Taylor and Francis Group.

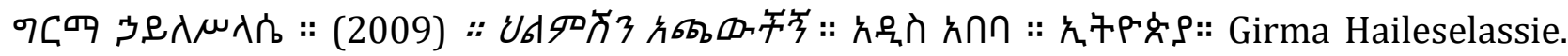
(2017). Hilmishn Achawuchign. Addis Ababa.Ethiopia. The Amharic Translation for Tell Me Your Dreams).

\section{Contact}

Alebachew Fentaw

Debark University

North Gondar Zone

Amhara Regional State

Ethiopia

alexfentaw2@gmail.com 